\title{
Trace metals in soft tissues of two marine gastropod molluscs: Monodonta turbinata B. and Patella caerulea $\mathbf{L}$. collected in a marine reference ecosystem
}

\author{
M. E. Conti ${ }^{1}$, M. Iacobucci ${ }^{2}$, M. Mecozzi ${ }^{3}$ \& G. Cecchetti ${ }^{2}$ \\ ${ }^{1}$ Dipartimento di Controllo e Gestione delle Merci e del loro Impatto \\ sull'Ambiente, Facoltà di Economia, Università "La Sapienza", Roma, \\ Italy \\ ${ }^{2}$ Centro per le Valutazioni Ambientali delle Attività Industriali, Facoltà \\ di Scienze Ambientali, Università degli Studi di Urbino, Urbino, Italy \\ ${ }^{3}$ Istituto Centrale per la Ricerca Scientifica e Tecnologica Applicata al \\ Mare, Via di Casalotti 300, 00166 Rome, Italy
}

\begin{abstract}
Monodonta turbinata B. and Patella caerulea $\mathrm{L}$. were evaluated as possible biomonitors of trace metal contamination in marine coastal areas. These species are marine gastropod molluscs; they are distributed in all coastal areas of the Mediterranean sea and are easy to identify and available all year round. They have the necessary prerequisites for use as biomonitors.

The first aim of this preliminary survey is to evaluate the concentrations of $\mathrm{Cd}, \mathrm{Cr}, \mathrm{Cu}, \mathrm{Pb}$ and $\mathrm{Zn}$ present in soft tissues of the selected species. Samples were collected in the tidal zone (1-2 meters depth) in a possible reference ecosystem (Linosa island, Sicily, Italy). Five coastal stations were selected according to the species availability. The second purpose was to establish the validity of these two gastropod species as bioaccumulators. The station number 4 (Pozzolana di Ponente) is the only site in Italy where the sea turtle Caretta caretta, annually deposes her eggs; thus this station is of a particular ecological relevance.

In order to test the bioaccumulation capabilities of these biomonitors seawater samples were collected in each site to assess soluble metal concentrations and then CFs. Seawater samples were collected appropriately in a 6-month period of sampling in the selected stations.

Statistical multivariate analyses, PCA, were applied to test the differences between metal concentrations in different sites and species. Results showed high results $(\mathrm{CFs})$ with respect to the concentrations in marine waters (soluble fraction). This confirmed the suitability of these species for biomonitoring purposes. PCA analysis showed clearly two separated patterns of bioaccumulation (i.e. Patella and Monodonta) and no significant differences ( $p=$ 0.05 ) for trace metal accumulation were obtained between the studied sites.

This finding agrees with the hypothesis of this island as reference ecosystem for intraspecific comparison within Tyrrhenian areas.
\end{abstract}




\section{Introduction}

Traditional methods (chemical analyses of water, air and sediments) of monitoring and control of pollution are very important and useful but they present a series of problems and limitations like considerable costs, methodological problems, numerous and wide samplings and in particular they not consider the effects on the living organisms.

The biomonitoring approach, introduced notable advantages in comparison to traditional analysis of abiotic matrixes (i.e. water and sediments). The evaluation of the bioavailability of the contaminants present in a marine ecosystem is a critical issue. Biomonitoring approaches have by now achieved a remarkable level. Molluscs are usually employed in international monitoring programs (i.e. Mussel Watch Program), in particular mussels that have a large diffusion in seas around the world. In absence of mussels, the choice of other possible organisms for biomonitoring purposes must be selected with particular attention [1].

They must be cosmopolitan and available all year round; they must accumulate the pollutant without being killed by the levels it comes in touch with; they must present a high concentration value of the contaminant and must be easy to sample and to preserve. Above all they must have a contaminant concentration that could be easily correlated with the concentration in the surrounding environment [2].

In the last years, many researchers have focused their attention in the identification of alternative species for their use as bioindicators of trace metal pollution in coastal areas. The goal of the present study was to gather more information on the use of the selected species as possible cosmopolitan biomonitors of trace metals present in the sea ecosystem of Linosa island.

Monodonta turbinata lives on the rocky seabeds of the intertidal belt. It tolerates different degrees of salinity as long as it stays fairly consistent. It can resist out of the water for several hours and it tolerates high temperatures. It eats algae and vegetable deposits that it scratches from the rocks. Monodonta is well distributed in the Mediterranean and in the Western Atlantic, from Portugal to Morocco and the Canaries. Patella caerulea lives on rocky substrata of tidelands at relatively shallow depths. It tolerates fairly long periods of time outside of water. It is only found in the Mediterranean, where is a popular food [3]. It is also important to underline that these herbivorous gastropods generally takes metals principally from the diet [4].

\section{Materials and methods}

Linosa island is situated in the Sicilian channel. It is $167 \mathrm{~km}$ far away from Sicily and $165 \mathrm{~km}$ from the African continent (Mahadia). Linosa is big $5.4 \mathrm{Km}^{2}$. In order to preserve the wealth of marine flora and fauna, the M. D. 21/10/2002, [5], decreed the creation of the Protected Sea Area of Linosa. Of particular relevance is the presence of the common turtle (Caretta caretta) which use the Linosa's beach for laying its eggs every year in the summer. In particular it uses the beach at the station 4, Pozzolana di Ponente (figure 1). 


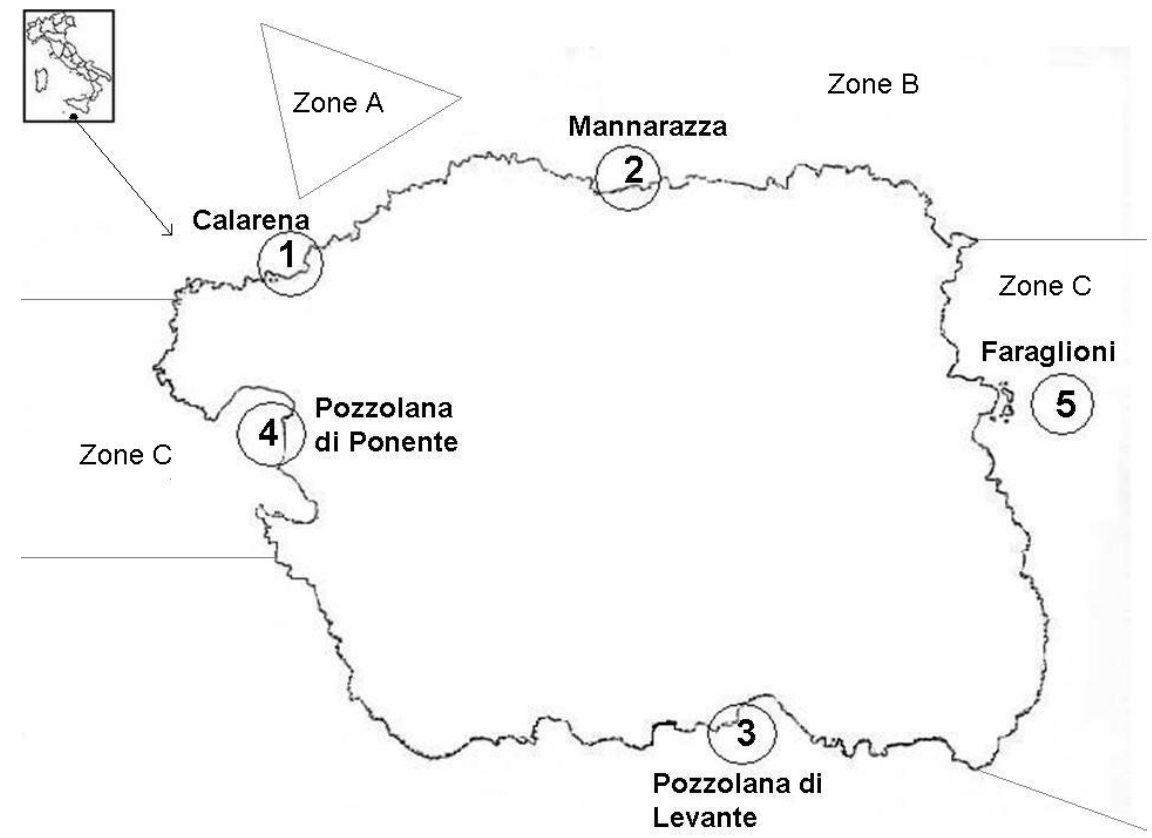

Figure 1: Sampling stations and areas of the Linosa island (Sicily, Italy): 1) Calarena, 2) Mannarazza, 3) Pozzolana di Levante, 4) Pozzolana di Ponente 5) Faraglioni; Zone A, Zone B and Zone C are the Protected Sea Areas.

The molluscs have been sampled in July 2004 in 5 stations situated along the coasts of the island (figure 1).

Various authors have classified the metals in three groups according to the seasonal influences. The first group ( $\mathrm{Mn}, \mathrm{Cu}, \mathrm{Co}, \mathrm{Ni}$ ) shows a gradual diminution of concentrations from winter to summer in seawater; while the second group $(\mathrm{Al}, \mathrm{Fe}, \mathrm{Pb})$ has an increase in the summer period (June), when the oxygen decreases and $\mathrm{PH}$ increases; the third group $(\mathrm{Zn}, \mathrm{Cd})$ show generally the same concentrations both in winter and in summer [6]. For these reasons, in the present research, we have chosen July, a month during which it can be hypothesized that mean levels of metals are at high levels in molluscs' tissues.

Individuals of Monodonta and Patella have been picked in the tidal zone, in varying number. Then they were immersed $(\mathrm{t}=24$ hours $)$ in filtered seawater to be purified [7]. The water had been drawn at the same stations where the samples were collected. Only individuals with a very similar weight (and size) were selected. Subsequently, the soft parts were taken out of the shell using tools (hammer and spatula) made exclusively of plastics, so as to prevent metal contamination, and then they were rinsed with deionized MilliQ water, in order to remove every residue of shell. Samples were immediately deep-frozen inside polyethylene bags. 
In order to assess CFs with the aim to observe the bioaccumulation ability of every single species, metal analyses of seawater were performed on metals in solution. Seawater analysis is a crucial step in biomonitoring studies due to the high variability of soluble metals in marine waters. In view of this, water samples $(\mathrm{n}=12)$ were collected once a month (as a duplicate) from February to July 2004, at a depth of $2 \mathrm{~m}$ with precleaned sampling bottles and rinsed twice with seawater.

The calculation of dry weight (d.w.) on the studied species (10 replicates for each location) was carried out through oven drying at $105^{\circ} \mathrm{C}$ until constant weight was achieved.

Mineralization was carried out using a microwave oven MDS-2100-CEM with a mixture of concentrated $\mathrm{HNO}_{3} / \mathrm{H}_{2} \mathrm{O}_{2}(5+2 \mathrm{~mL})$. Metal concentrations in molluscs were measured using Perkin Elmer AAnalyst 300 atomic absorption spectrophotometer with flame atomization (FAAS) and graphite furnace system (GFAAS) with HGA 800 autosampler. For $\mathrm{Cu}$ and $\mathrm{Zn}$, flame atomization was employed, while for $\mathrm{Cd}, \mathrm{Cr}$ and $\mathrm{Pb}$ GFAAS was used. For $\mathrm{Cd}$ and $\mathrm{Pb}$, matrix modifier $\mathrm{NH}_{4} \mathrm{H}_{2} \mathrm{PO}_{4}^{-3}$ at $10 \%$ with $0.2 \mathrm{mg}$ of $\mathrm{PO}_{4}{ }^{-3}$ was used, while for $\mathrm{Cr}$, was employed $\mathrm{Mg}\left(\mathrm{NO}_{3}\right)_{2}$. The procedure for water samples analysis is described elsewhere [8].

The limits of detection (LODs) were calculated on the basis of 15 determinations of the blanks as 3 times the standard deviation of the blank. Results of molluscs LODs were: $\mathrm{Cd}=0.05 \mu \mathrm{g} / \mathrm{L}, \mathrm{Cr}=0.94 \mu \mathrm{g} / \mathrm{L}, \mathrm{Cu}=0.01$ $\mathrm{mg} / \mathrm{L}, \mathrm{Pb}=0.09 \mu \mathrm{g} / \mathrm{L}$ and $\mathrm{Zn}=0.09 \mathrm{mg} / \mathrm{L}$. LODs for seawater were: $\mathrm{Cd}=22$ $\mathrm{ng} / \mathrm{L}, \mathrm{Cr}=19 \mathrm{ng} / \mathrm{L}, \mathrm{Cu}=41 \mathrm{ng} / \mathrm{L}, \mathrm{Pb}=23 \mathrm{ng} / \mathrm{L}$ and $\mathrm{Zn}=57 \mathrm{ng} / \mathrm{L}$.

The accuracy of the mineralization procedures was controlled using certified reference materials: ERM CE 278 (mussel tissue) and CRM 403 (seawater). One sample of ERM (or CRM) and blanks were included in each analytical batch. Results are in agreement with certified values with the followings recoveries: $96 \%$ for $\mathrm{Cd}, 101 \%$ for $\mathrm{Cr}, 99 \%$ for $\mathrm{Cu}, 104 \%$ for $\mathrm{Pb}$ and $99 \%$ for $\mathrm{Zn}$. This confirms the good quality of all analytical procedures.

Principal Component Analysis (PCA) was performed on standardised matrix of metal data coming from Linosa Island by means of the Statistica software (StatSoft ,OK, USA) version 5 for Windows environment.

\section{Results}

Table 1 shows mean metal concentrations obtained by the analyses of the molluscs and mean dissolved metal concentrations of 12 replicates of water samples. Mean levels in biota are referred to dry weight to reduce variability of measurements determined by habitat, life conditions, pretreatment and conservation of organisms after sampling [1].

In $P$. caerulea metal concentrations, decreased in the following order: $\mathrm{Zn}>$ $\mathrm{Cu}>\mathrm{Cd}>\mathrm{Pb}>\mathrm{Cr}$; this agrees with our previous data reported for the Gulf of Gaeta and Ustica island $[9,10]$. For Patella the values obtained were in the range 
of 2.69-4.97 $\mu \mathrm{g} \mathrm{g}^{-1} \mathrm{dw}$ for $\mathrm{Cd}$; $0.13-0.75 \mu \mathrm{g} \mathrm{g}^{-1} \mathrm{dw}$ for $\mathrm{Cr}$; 2.78-9.71 $\mu \mathrm{g} \mathrm{g}^{-1} \mathrm{dw}$ for $\mathrm{Cu}$; $0.40-2.41 \mu \mathrm{g} \mathrm{g}^{-1} \mathrm{dw}$ for $\mathrm{Pb}$ and 38.40-51.47 $\mu \mathrm{g} \mathrm{g}^{-1} \mathrm{dw}$ for $\mathrm{Zn}$.

For Monodonta the values obtained were in the range of $0.77-1.28 \mu \mathrm{g} \mathrm{g}^{-1} \mathrm{dw}$ for $\mathrm{Cd}$; $0.15-1.30 \mu \mathrm{g} \mathrm{g}^{-1} \mathrm{dw}$ for $\mathrm{Cr}$; 10.13-34.89 $\mu \mathrm{g} \mathrm{g}^{-1} \mathrm{dw}$ for $\mathrm{Cu}$; 0.62-1.78 $\mu \mathrm{g}$ $\mathrm{g}^{-1} \mathrm{dw}$ for $\mathrm{Pb}$ and 50.21-60.90 $\mu \mathrm{g} \mathrm{g}^{-1} \mathrm{dw}$ for $\mathrm{Zn}$. As to Monodonta metal concentrations decreased in the following order: $\mathrm{Zn}>\mathrm{Cu}>\mathrm{Pb}>\mathrm{Cd}>\mathrm{Cr}$.

To assess the existence of significant differences in the metal concentrations in molluscs, use of multivariate analysis (principal component analysis, PCA) was taken into account.

The application of PCA showed that three components were able to explain the $85.84 \%$ of total variance (figure 2 ). In the first factor accounting the highest fraction of variance $(52.62 \%)$ the most significant metals were $\mathrm{Cu}$ and $\mathrm{Cr}$ which had the highest loading values, 0.90 and 0.80 respectively (see table 2). $\mathrm{Cd}$ and $\mathrm{Zn}$ showed also significant loading values (-0.69 and 0.66$)$. In the second factor accounting a lower fraction of total variance $(20.00 \%)$, only $\mathrm{Pb}$ showed a significant loading (0.76). So this result shows that most significant elements in determining the pollutant distribution are $\mathrm{Cu}>\mathrm{Cr}>\mathrm{Cd} \approx \mathrm{Zn}>\mathrm{Pb}$.

Table 1: Concentrations of metals ( $\mu \mathrm{g} \mathrm{g}^{-1}$ d.w.) in the soft tissues of $P$. caerulea and $M$. turbinata (means \pm SD) and mean dissolved metal concentrations in seawater (means $\pm \mathrm{SD}$ ).

\begin{tabular}{|c|c|c|c|c|c|c|}
\hline $\begin{array}{c}\text { Sampling } \\
\text { station }\end{array}$ & Ind. & Cd & $\mathrm{Cr}$ & $\mathbf{C u}$ & $\mathbf{P b}$ & Zn \\
\hline \multicolumn{7}{|l|}{$\begin{array}{l}\text { Patella } \\
\text { caerulea }^{a}\end{array}$} \\
\hline 1 & 8 & $3.25 \pm 0.86$ & $0.27 \pm 0.08$ & $2.78 \pm 0.88$ & $0.40 \pm 0.11$ & $41.78 \pm 10.13$ \\
\hline 2 & 8 & $3.68 \pm 1.01$ & $0.24 \pm 0.10$ & $6.22 \pm 1.61$ & $0.47 \pm 0.15$ & $38.40 \pm 6.26$ \\
\hline 3 & 8 & $3.26 \pm 0.97$ & $0.75 \pm 0.22$ & $4.04 \pm 1.35$ & $1.28 \pm 0.31$ & $41.47 \pm 6.87$ \\
\hline 4 & 8 & $2.69 \pm 0.63$ & $0.72 \pm 0.21$ & $9.71 \pm 2.25$ & $2.41 \pm 0.65$ & $42.84 \pm 4.44$ \\
\hline 5 & 8 & $4.97 \pm 1.31$ & $0.13 \pm 0.04$ & $6.60 \pm 1.14$ & $0.51 \pm 0.09$ & $51.47 \pm 9.62$ \\
\hline \multicolumn{7}{|l|}{$\begin{array}{l}\text { Monodonta } \\
\text { turbinata }^{b}\end{array}$} \\
\hline 1 & 8 & $0.77 \pm 0.23$ & $0.45 \pm 0.10$ & $10.13 \pm 2.81$ & $1.66 \pm 0.63$ & $50.21 \pm 2.27$ \\
\hline 2 & 8 & $1.17 \pm 0.28$ & $0.38 \pm 0.08$ & $15.31 \pm 3.82$ & $0.71 \pm 0.22$ & $50.47 \pm 6.23$ \\
\hline 3 & 8 & $1.11 \pm 0.20$ & $1.30 \pm 0.38$ & $34.89 \pm 9.78$ & $1.07 \pm 0.25$ & $60.90 \pm 8.63$ \\
\hline 4 & 8 & $1.11 \pm 0.32$ & $0.94 \pm 0.28$ & $28.26 \pm 4.90$ & $1.78 \pm 0.49$ & $59.29 \pm 4.89$ \\
\hline 5 & 8 & $1.28 \pm 0.35$ & $0.15 \pm 0.04$ & $12.30 \pm 2.37$ & $0.62 \pm 0.13$ & $56.26 \pm 8.10$ \\
\hline \multicolumn{2}{|c|}{$\begin{array}{l}\text { Dissolved metals } \\
\quad\left(\mu \mathrm{g} \mathrm{L}^{-1}\right)\end{array}$} & $0.16 \pm 0.04$ & $0.18 \pm 0.02$ & $0.96 \pm 0.08$ & $0.68 \pm 0.15$ & $10.66 \pm 1.11$ \\
\hline
\end{tabular}

${ }^{\mathrm{a}}$ Mean length (cm): $2.5{ }^{\mathrm{b}}$ shell size (cm) 2.5 (mean height). 
3D Scoreplot of Linosa data

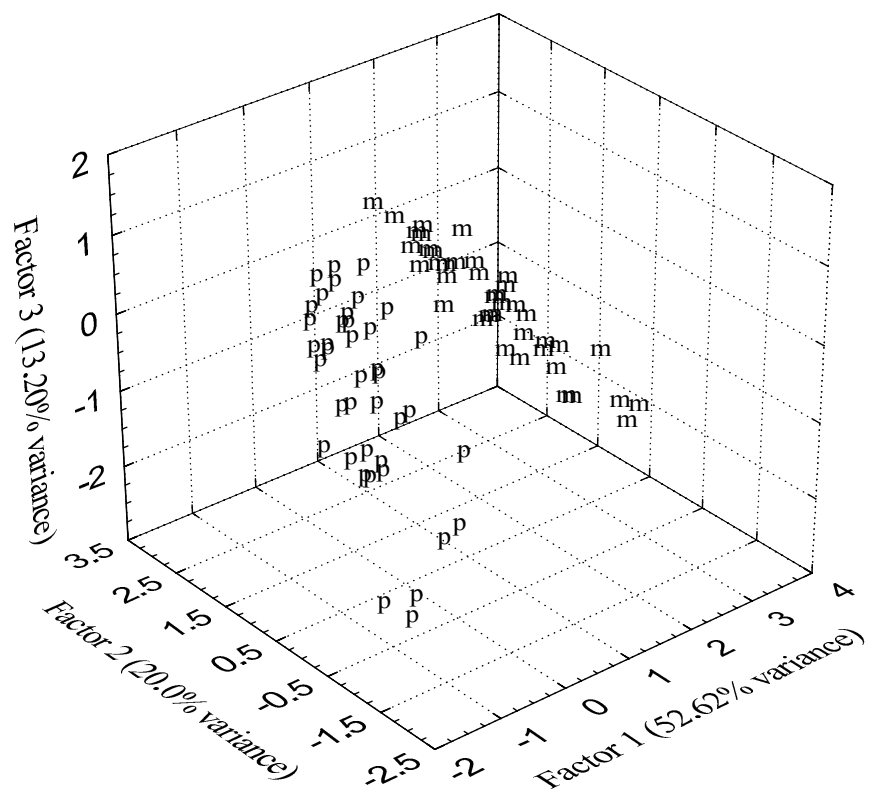

Figure 2: 3D plot of PCA applied to data form Linosa. "m" is Monodonta, "p" is Patella. The plot explains the $85.82 \%$ of total variance.

Table 2: $\quad$ Loadings obtained by PCA.

\begin{tabular}{|c|c|c|c|c|}
\hline & FACTOR 1 & FACTOR 2 & FACTOR 3 & FACTOR 4 \\
\hline Cu & 0.900581 & -0.216787 & -0.081273 & 0.159400 \\
\hline $\mathbf{Z n}$ & 0.662907 & -0.561107 & -0.223015 & -0.419942 \\
\hline $\mathbf{C d}$ & -0.692997 & 0.016577 & -0.715285 & -0.009693 \\
\hline Pb & 0.0506059 & 0.761798 & -0.079567 & -0.392309 \\
\hline $\mathbf{C r}$ & 0.802631 & 0.240670 & -0.292031 & 0.406967 \\
\hline Expl. Var. & $52.62 \%$ & $20.00 \%$ & $13.19 \%$ & 0.104276 \\
\hline
\end{tabular}

The scoreplots allowed to see how the pollutant distribution is related more significantly to species than to sites. In the scoreplot of figure 2 where the data were reported according to the living organism it is evident a marked separation between the accumulation patterns of data of the two molluscs species. Above all the data for Monodonta are placed in the plot portion with the highest value of the first factor, it means that they have the highest accumulation of all the pollutants with $\mathrm{Cu}$ and $\mathrm{Cr}$ in particular.

In the same scoreplot reported this time according to the different sites (figure 3) the data are placed without a marked separations and many sites are present overlapped with other sites. Faraglioni site only is placed well separated from the other sites, but this separations always depends on the specie (i.e. 
Patella) as for the Monodonta, Faraglioni site is overlapped with other sites. This results seem to confirm that there is non-significant differences between sites and is no one site more contaminated than another. This finding agrees with the hypothesis as Linosa island as a possible reference ecosystem.

At last, the correlation matrix (table 3) showed some correlations (at 95\% of statistical significance). $\mathrm{Cu}$ is correlated to $\mathrm{Zn}$ and $\mathrm{Cu}$ showing a probable common origin whereas $\mathrm{Pb}$ and $\mathrm{Cd}$ do not show correlation with the other elements.

With reference to mean soluble metals concentrations reported in table 2, CFs for both species were calculated. CFs were obtained by the ratio between the mean metal concentration in the organism and the mean dissolved metal concentration in the seawater. For Patella the CFs $\times 10^{3}$ were: 22.31 for $\mathrm{Cd}$, 2.33 for $\mathrm{Cr}, 6.11$ for $\mathrm{Cu}, 1.49$ for $\mathrm{Pb}$ and 4.05 for $\mathrm{Zn}$. For Monodonta the CFs $\times$ $10^{3}$ were: 6.75 for $\mathrm{Cd}, 3.56$ for $\mathrm{Cr}, 20.83$ for $\mathrm{Cu}, 1.59$ for $\mathrm{Pb}$ and 5.16 for $\mathrm{Zn}$.

Regarding net accumulation we can observe that Patella is the better accumulator of $\mathrm{Cd}$ while Monodonta is the strongest accumulator of $\mathrm{Cu}$, this result agrees with our previous studies [8,9]. The high CFs values obtained for these species for the studied metals confirms the good suitability of these species for biomonitoring purposes.

3D Scoreplot of Linosa data

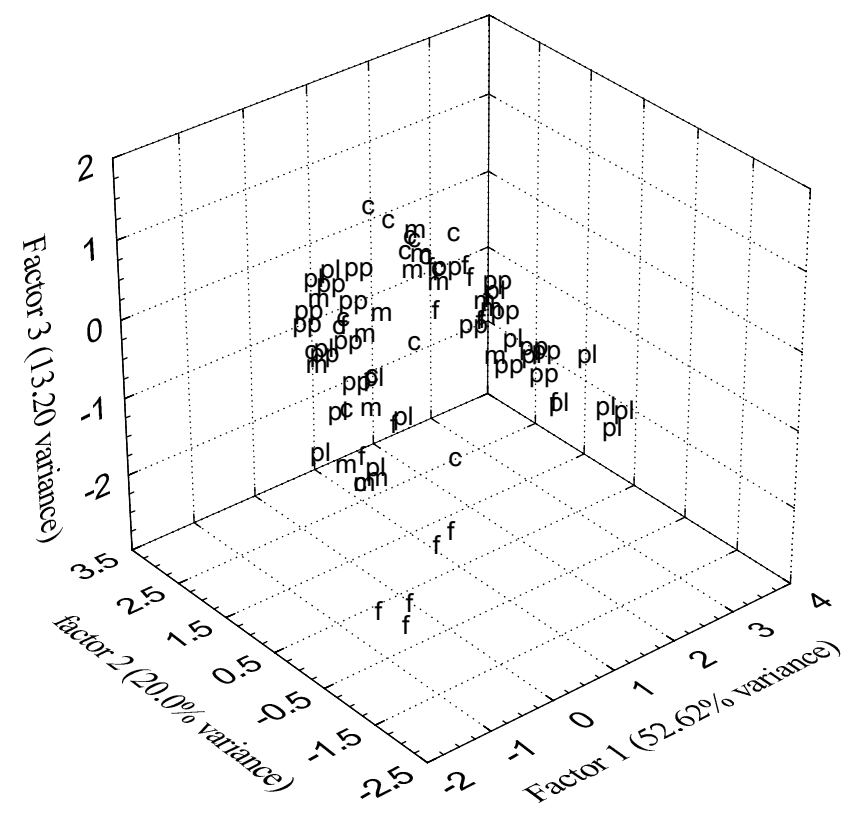

Figure 3: 3D plot of PCA applied to Linosa data. "c" Calarena, "m" Manarazza, "pl" Pozzolana di Levante, "pp" Pozzolana di Ponente, "f” Faraglioni. 
Table 3: Correlation matrix of trace metals. Significant correlation values are reported in bold.

\begin{tabular}{|c|c|c|c|c|}
\hline & $\mathbf{C u}$ & $\mathrm{Zn}$ & $\mathrm{Cd}$ & $\mathrm{Pb}$ \\
\hline $\mathrm{Cu}$ & & & & \\
\hline $\mathbf{Z n}$ & $\mathbf{0 . 6 2 3 3 7 7}$ & & & \\
\hline $\mathrm{Cd}$ & -0.54191 & -0.31744 & & \\
\hline $\mathrm{Pb}$ & 0.253669 & 0.082427 & -0.27227 & \\
\hline $\mathbf{C r}$ & $\mathbf{0 . 6 8 7 4 1 2}$ & 0.321612 & -0.36637 & 0.440593 \\
\hline
\end{tabular}

\section{Conclusions}

The use of two gastropods turned out to be very valuable for the study of a coastal area with a low levels of contamination. The two species studied can be considered as a potential biomonitors of trace metal pollution.

Statistical multivariate analysis (PCA) revealed two clearly separated patterns of bioaccumulation for the studied species respectively.

Statistical results confirmed that most significant elements in determining the pollutant distribution were $\mathrm{Cu}>\mathrm{Cr}>\mathrm{Cd} \approx \mathrm{Zn}>\mathrm{Pb}$.

Above all, the data for Monodonta are placed in the plot portion (PCA) with the highest value of the first factor, it means that it has the higher levels of accumulation of pollutants with particularly high levels of $\mathrm{Cu}$ and $\mathrm{Cr}$. These results were also supported by the high levels of the obtained $\mathrm{CFs}$. $\mathrm{Cu}$ showed good correlation with $\mathrm{Zn}$ and $\mathrm{Cd}$. These findings can be attributed a probable common origin whereas $\mathrm{Pb}$ and $\mathrm{Cd}$ do not showed correlation with the other studied trace metals. Patella resulted the strongest accumulator of $\mathrm{Cd}$.

Metal levels in biomonitors were generally in the lower levels of literature data $[9,10]$, this agrees with the hypothesis of Linosa island as a possible reference ecosystem for the studied pollutants. The follow-up of this study extended to other biomonitors might further confirm these initial results.

\section{References}

[1] Conti, M.E., Il monitoraggio biologico della qualità ambientale, ed. SEAM: Roma, pp. 35-38, 2002.

[2] Phillips, D. \& Segar, D. A., Use of bio-indicators in monitoring conservative contaminants: programme design imperatives. Marine Pollution Bulletin, 26, pp. 593-601, 1986.

[3] Torelli A. Gasteropodi Conchigliati-Guide per il riconoscimento delle acque lagunari e costiere italiane, Consiglio Nazionale delle Ricerche, 235pp., Genova, 1982.

[4] Ahn I.-Y., Kim K.-W. \& Choi H.J. A baseline study on metal concentrations in the Antarctic limpet Nacella concinna (Gastropoda: Patellidae) on King George Island: variations with sex and body parts, Marine Pollution Bulletin, 44, 421-431, 2002. 
[5] G.U. n.14, 18/01/2003.

[6] Volterra L. \& Conti M.E. Algae as biomarkers, bioaccumulators and toxin procedure, Int. J. Environment and Pollution, Vol.13, Nos.1-6, p.92, 2002.

[7] Pempkowiak J., Sikora A. \& Biernacka E. Speciation of heavy metals in marine sediments vs their bioaccumulation by mussel, Chemosphere, Vol.39, No.2, pp.313-321,1999.

[8] Conti, M.E. \& Cecchetti, G., A biomonitoring study: trace metals in algae and molluscs from Tyrrhenian coastal areas. Environmental Research, 93, pp. 99-112, 2003.

[9] Campanella, L., Conti, M.E., Cubadda, F. \& Sucapane, C., Trace metals in seagrass, algae and molluscs from an uncontaminated area in the Mediterranean. Environmental Pollution, 111, pp. 117-126, 2001.

[10] Conti, M.E., Iacobucci, M. \& Cecchetti, G., The biomonitoring approach as a tool of trace metal assessment in an uncontaminated marine ecosystem: Ustica island (Sicily, Italy), in: Geo-Environment, Monitoring, Simulation and Remediation of the Geological Environment; J.F. Martin-Duque, C.A. Brebbia, A.E. Godfrey, J.R. Dìaz de Teràn (Eds.), WITpress, 335-344, 2004. 